\title{
Leptin Contributes to Neuropathic Pain via Extrasynaptic NMDAR-nNOS Activation
}

\author{
Yanling Liang ${ }^{1} \cdot$ Yuxin $\mathrm{Ma}^{2} \cdot$ Jieqin Wang ${ }^{3} \cdot$ Lei Nie $^{4} \cdot \mathrm{Xusheng} \mathrm{Hou}^{5} \cdot$ Wenyu Wu ${ }^{6} \cdot \mathrm{Xingmei} \mathrm{Zhang}^{1}$. \\ Yinghong $\operatorname{Tian}^{7}$ (ID
}

Received: 26 June 2020 / Accepted: 14 October 2020 / Published online: 25 October 2020

(C) The Author(s) 2020

\begin{abstract}
Leptin is an adipocytokine that is primarily secreted by white adipose tissue, and it contributes to the pathogenesis of neuropathic pain in collaboration with N-methyl-D-aspartate receptors (NMDARs). Functional NMDARs are a heteromeric complex that primarily comprise two NR1 subunits and two NR2 subunits. NR2A is preferentially located at synaptic sites, and NR2B is enriched at extrasynaptic sites. The roles of synaptic and extrasynaptic NMDARs in the contribution of leptin to neuropathic pain are not clear. The present study examined whether the important role of leptin in neuropathic pain was related to synaptic or extrasynaptic NMDARs. We used a rat model of spared nerve injury (SNI) and demonstrated that the intrathecal administration of the NR2A-selective antagonist NVP-AAM077 and the NR2B-selective antagonist Ro25-6981 prevented and reversed mechanical allodynia following SNI. Administration of exogenous leptin mimicked SNI-induced behavioral allodynia, which was also prevented by NVP-AAM077 and Ro25-6981. Mechanistic studies showed that leptin enhanced NR2B- but not NR2A-mediated currents in spinal lamina II neurons of naïve rats. Leptin also upregulated the expression of NR2B, which was blocked by the NR2B-selective antagonist Ro25-6981, in cultured dorsal root ganglion (DRG) neurons. Leptin enhanced neuronal nitric oxide synthase (nNOS) expression, which was also blocked by Ro25-6981, in cultured DRG cells. However, leptin did not change NR2A expression, and the NR2A-selective antagonist NVP-AAM077 had no effect on leptin-enhanced nNOS expression. Our data suggest an important cellular link between the spinal effects of leptin and the extrasynaptic NMDAR-nNOS-mediated cellular mechanism of neuropathic pain.
\end{abstract}

Keywords Neuropathic pain $\cdot$ Leptin $\cdot$ NMDAR $\cdot$ Synaptic $\cdot$ Extrasynaptic

\section{Introduction}

Neuropathic pain resulting from injury of the peripheral or central nervous system has several clinical features, including hyperalgesia, allodynia, and spontaneous pain. N-Methyl-D-

Yanling Liang and Yuxin Ma contributed equally to this work.

Xingmei Zhang

zxmray@hotmail.com

$\triangle$ Yinghong Tian

510918051@qq.com

1 Key Laboratory of Mental Health of the Ministry of Education, Guangdong-Hong Kong-Macao Greater Bay Area Center for Brain Science and Brain-Inspired Intelligence, Guangdong Province Key Laboratory of Psychiatric Disorders, Department of Neurobiology, School of Basic Medical Sciences, Southern Medical University, No. 1838 Guangzhou Avenue, Guangzhou 510515, China

2 Department of Anatomy, School of Life Sciences and Biopharmaceutics, Guangdong Pharmaceutical University, Guangzhou 510006, China aspartate receptors (NMDARs) play a crucial role in the mechanisms of peripheral and central sensitization of neuropathic pain [1-4]. There are three main families of NMDAR subunits: NR1, a family of NR2 subunits (NR2A, NR2B, NR2C and NR2D); and two NR3 subunits (NR3A and

3 Department of Pancreatobiliary Surgery, The First Affiliated Hospital of Sun Yat-sen University, Guangzhou 510515, China

4 Department of Anesthesiology, The Third Xiangya Hospital of Central South University, Changsha 410000, China

5 Department of Functional Neurosurgery, Zhujiang Hospital, Southern Medical University, Guangzhou 510515, China

6 Target and Interventional Therapy Department of Oncology, First People's Hospital of Foshan, Foshan 528000, China

7 Experiment Teaching \& Administration Center, School of Basic Medical Sciences, Southern Medical University, No. 1838 Guangzhou Avenue, Guangzhou 510515, China 
NR3B). Functional NMDARs are a heteromeric complex and primarily comprise two NR1 subunits and two NR2 subunits. Synaptic and extrasynaptic NMDARs comprise different subtypes. NR2A predominates at synaptic sites, and NR2B is mostly expressed at extrasynaptic sites in mature neurons in the hippocampus and cortex $[5,6]$, the spinal dorsal horn and dorsal root ganglion (DRG) [7-10]. NR2D is expressed to a lesser extent at extrasynaptic sites in the spinal dorsal horn [9]. $\mathrm{NR} 2 \mathrm{C}$ is enriched in the cerebellum and rarely expressed in other brain regions $[11,12]$.

NR2A and NR2B have different functions. NR2A plays a role in long-term potentiation (LTP), and NR2B is primarily involved in the production of long-term depression (LTD) $[13,14]$. In ischemia- and brain trauma-induced neuronal injury, synaptic NMDAR activation promotes neuronal survival, and extrasynaptic NMDAR activation results in neuronal death [15-18]. NR2B plays an important role in the development of neuropathic pain in nerve injury animal models [19-24]. However, whether NR2A is involved in neuropathic pain is controversial [19, 24-27].

Leptin is a $16-\mathrm{kDa}$ adipocytokine that is primarily secreted by white adipose tissue. It is well known for its role in metabolic regulation and obesity, which are mediated via a long-form leptin receptor (Ob-Rb) [28-31]. Leptin and $\mathrm{Ob}-\mathrm{Rb}$ were recently found in the CNS, which indicates that leptin has a broad role in the regulation of neuronal functions [32, 33]. Recent studies showed that leptin played a significant role in nerve injury-induced neuropathic pain in rats $[34,35]$. The peripheral effects of leptin on neuropathic pain following nerve injury were mediated via macrophage stimulation [36], and our previous results indicated that the central effect of leptin was likely related to the activation of NMDARs [34, 35].

Synaptic and extrasynaptic NMDARs contain different subunits, and leptin contributes to the pathogenesis of neuropathic pain via activation of NMDARs. Therefore, the present study further investigated whether leptin contributed to neuropathic pain via synaptic or extrasynaptic NMDARs. Synaptic NMDARs in the spinal cord and DRG primarily comprise NR1/NR2A, and extrasynaptic NMDARs consist of NR1/NR2B and NR1/NR2D [7-10]. However, NR2D does not play a role in the occurrence or development of pain sensation [19, 37], Therefore, we focused on the role of NR2A and NR2B in the contribution of leptin to neuropathic pain.

Neuronal nitric oxide synthase (nNOS) plays an important role in the development and maintenance of neuropathic pain $[22,38-40]$, and it is a downstream factor of NR2B [19, 22, $41,42]$. The present study also investigated whether leptin contributed to neuropathic pain via synaptic or extrasynaptic NMDAR-nNOS activation. Our results indicated that spinal leptin played an important role in the pathogenesis of neuropathic pain via activation of the extrasynaptic NMDARnNOS pathway.

\section{Materials and Methods}

\section{Experimental Animals}

Male Sprague-Dawley rats, 4-6 weeks old, were used for electrophysiological experiments and primary culture of DRG neurons. Rats weighing 250-280 g were used for behavioral experiments. All SD rats were purchased from Southern Medical University Animal Center (Guangzhou, Guangdong, China). The rats were given sufficient food and water and maintained on a 12:12-h light/dark cycle in an SPF animal room at $22-25^{\circ} \mathrm{C}$ with $45 \pm 10 \%$ humidity. All animal protocols were approved by the Animal Experimentation Ethics Committee of Southern Medical University and performed in accordance with the principles of the 'Administrative Measures for Laboratory Animals of Southern Medical University' and the 'Guidelines for Ethical Examination of Animal Experiments of Southern Medical University'.

\section{Drugs}

N-Methyl-D-aspartate (NMDA), glycine, strychnine, bicuculline methochloride, 2,3-dioxo-6-nitro-1,2,3,4tetrahydrobenzo [f] quinoxaline-7-sulfonamide (NBQX), NVP-AAM077, (+)-5-methyl-10,11-dihydro-5H-dibenzo(a, b)cyclohepten-5,10-imine maleate (MK-801), poly-1-lysine, and cytarabine were purchased from Sigma-Aldrich (St. Louis, MO, USA). Leptin was purchased from Abcam (San Francisco, CA, USA). Ro25-6981 and tetrodotoxin were purchased from Tocris (Ellisville, MI, USA). All drugs were dissolved in water or saline.

\section{Spared Nerve Injury And Drug Delivery}

Spared nerve injury (SNI) was produced according to the method of Decosterd and Woolf [43]. Briefly, rats weighing 280-300 g were anesthetized using pentobarbital sodium (50 $\mathrm{mg} / \mathrm{kg}$, intraperitoneal). The skin of the lateral left thigh was incised, and the biceps femoris muscle was separated to expose the sciatic nerve and its three terminal branches: the sural, common peroneal, and tibial nerves. The common peroneal and tibial nerves were tightly ligated, and a $2-\mathrm{mm}$ length segment close to the ligation was removed. The intact sural nerve was untouched. The wound was stitched in two layers.

Intrathecal injections were performed following the procedures described by Wei [44]. A sterile catheter (PE-10 tube) was inserted through the L5/L6 intervertebral space until the tip of the catheter reached spinal lumbar enlargement (approximately $4.5 \mathrm{~cm}$ from the incision site for this rat age group). Any rats with hind limb paralysis or paresis after surgery were excluded. Drugs or vehicle were administered using a 
microsyringe $(25 \mu \mathrm{l})$ in a $10-\mu \mathrm{l}$ volume followed by $10 \mu \mathrm{l}$ of saline to flush the dead space in the catheter. Rats were injected intrathecally once daily for 14 days with leptin $(50 \mu \mathrm{g})$, Ro25-6981 (20 nmol), NVP-AAM077 (4 nmol), leptin $(50 \mu \mathrm{g})$ plus Ro25-6981 $(20 \mathrm{nmol})$, leptin $(50 \mu \mathrm{g})$ plus NVP-AAM077 (4 nmol), or saline. The doses were based on references and our previous results $[15,34,35,48]$.

\section{Behavioral Test for Allodynia}

Rats were habituated to the test environment for $1 \mathrm{~h}$ over 2 consecutive days before baseline testing. Mechanical allodynia was examined using von Frey filaments applied to the plantar surface of each hind paw [45]. A positive response was defined as hind paw withdrawal from at least 2 of 5 applications of a von Frey filament. The paw withdrawal threshold (PWT) was determined using the "up-and-down" method [46]. Food intake and body weight were monitored to exclude the effects of these two factors. All behavioral experiments were carried out at $9 \mathrm{AM}$, and the investigators were blinded to treatment conditions.

\section{Preparation of Spinal Cord Slices}

Lumbar spinal cord slices were prepared from postnatal day 4to 6-week-old male SD rats. Laminectomy was performed after pentobarbital sodium anesthesia, and a portion of the lumbar spinal cord (L4-L6) was removed and placed in chilled, oxygenated $\left(95 \% \mathrm{O}_{2}+5 \% \mathrm{CO}_{2}\right)$ artificial cerebrospinal fluid (ACSF) containing (mM) $125 \mathrm{NaCl}, 2.5 \mathrm{KCl}, 26$ $\mathrm{NaHCO}_{3}, 1.25 \mathrm{NaH}_{2} \mathrm{PO}_{4}, 2 \mathrm{CaCl}_{2}, 2 \mathrm{MgCl}_{2}$, and $25 \mathrm{D}$-glucose. Transverse slices $(350 \mu \mathrm{m})$ were cut on a vibratome (Bannockburn, IL, USA). Spinal cord slices were incubated in oxygenated ACSF at $32{ }^{\circ} \mathrm{C}$ for $30 \mathrm{~min}$ then at room temperature $\left(22-25^{\circ} \mathrm{C}\right)$ for at least $1 \mathrm{~h}$ before electrophysiological recording.

\section{Electrophysiological Recording}

Electrophysiological recording was described previously [35]. Briefly, whole-cell patch-clamp recordings were made from lamina II (substantia gelatinosa) neurons of spinal cord slices using glass patch pipettes $(1.5 \mathrm{~mm}$ outer diameter, $3-5 \mathrm{~m} \Omega$ resistance). The internal solution contained (mM) $140 \mathrm{~K}$-gluconate, $2 \mathrm{MgCl}_{2}, 1 \mathrm{CaCl}_{2}, 11$ EGTA, 10 HEPES, $5 \mathrm{Mg}$-ATP, and $0.5 \mathrm{Na}-\mathrm{GTP}, \mathrm{pH}$ 7.3. NMDA currents were evoked by ejecting $50 \mu \mathrm{M}$ NMDA plus $10 \mu \mathrm{M}$ glycine in $\mathrm{Mg}^{2+}$-free ACSF for $30 \mathrm{~s}$ at a holding potential of $-70 \mathrm{mV}$ (Stoelting, Kiel, WI, USA). The ejection solution also contained $1 \mu \mathrm{M}$ strychnine, $10 \mu \mathrm{M}$ bicuculline, $10 \mu \mathrm{M} \mathrm{NBQX}$, and $1 \mu \mathrm{M}$ tetrodotoxin to block glycine receptors, $\mathrm{GABA}_{\mathrm{A}}$ receptors, AMPA receptors, and voltage-gated sodium channels, respectively. Once the baseline NMDA current was acquired, $100 \mathrm{nM}$ leptin and/or NVP-AAM077 $(0.4 \mu \mathrm{M})$ and Ro25-6981 $(1 \mu \mathrm{M})$ were bath-applied for $5 \mathrm{~min}$. All electrophysiological experiments were performed at room temperature $\left(22-25^{\circ} \mathrm{C}\right)$.

\section{Primary Culture of Rat DRG Neurons}

Male SD rats, 4- to 6-weeks-old, were used for the primary culture of DRG neurons [47]. Ganglia from the cervical to the lumbar levels were removed and cut into pieces using a pair of scleral scissors. After enzymatic and mechanical dissociation, the cell suspension was seeded in a poly-1-lysine-coated 96well plate or 6-well plate. Cultures were maintained at $37{ }^{\circ} \mathrm{C}$ in a humidified $95 \%$ air $/ 5 \% \mathrm{CO}_{2}$ incubator (Thermo Scientific, USA) for 3 days in DMEM (Gibco, USA) with $10 \%$ serum. The DRG neurons were cultured in medium containing leptin (100 nM), Ro25-6981 (1 $\mu \mathrm{M})$, NVP-AAM077 $(0.4 \mu \mathrm{M})$, leptin $(100 \mathrm{nM})$ plus Ro25-6981 $(1 \mu \mathrm{M})$ or NVPAAM077 $(4 \mu \mathrm{M})$ for 3 more days. The doses were based on references and our previous results [15, 34, 35, 48].

\section{Immunocytochemistry}

Cultured DRG neurons in 96-well plates were fixed with $4 \%$ paraformaldehyde for $2 \mathrm{~h}$, blocked with bovine serum albu$\min (3 \% \mathrm{v} / \mathrm{v}$, Sigma, USA) and Triton-X100 (0.3\% v/v, Sigma, USA) for $1.5 \mathrm{~h}$ at room temperature and incubated overnight at $4{ }^{\circ} \mathrm{C}$ with one of the following primary antibodies: NR2A (Novus, USA) at 1:500, mouse monoclonal; NR2B (Abcam, USA) at 1:1000, rabbit polyclonal; and nNOS (BD Biosciences, USA) at 1:1000, mouse monoclonal. Cells were rinsed with PBS and incubated for $1.5 \mathrm{~h}$ at room temperature with an FITC- or cyanine 3-conjugated secondary antibody (1:300; Jackson ImmunoResearch, USA). For controls, primary antibodies were omitted in the process. Four to 6 wells were randomly selected for examination using a fluorescence microscope attached to a CCD spot camera (Olympus IX71, Japan) and processed using Adobe Photoshop v7.

\section{Western Blot Analysis}

Cultured DRG neurons in 6-well plates were lysed in RIPA buffer (Thermo Scientific, USA) supplemented with protease inhibitors (Thermo Scientific, USA). Debris was sedimented via centrifugation at $14,000 \mathrm{~g}$ for $10 \mathrm{~min}$ at $4{ }^{\circ} \mathrm{C}$, and the supernatant was collected. The protein concentration was detected using a BCA protein assay kit (Thermo Scientific, USA). Proteins were separated using $8 \%$ SDS-PAGE gels and transferred to polyvinylidene fluoride (PVDF) membranes (Millipore, Bedford, USA). Membranes were blocked with $5 \%$ nonfat dried milk and incubated overnight $\left(4{ }^{\circ} \mathrm{C}\right)$ with anti-NR2A antibody (BOSTER, China: 1:400, rabbit polyclonal), anti-NR2B antibody (Abcam, USA: 1:1000, rabbit polyclonal) [49] and anti-nNOS antibody (BD 
Biosciences, USA: 1:1000, mouse monoclonal). Membranes were rinsed with TBST and incubated with an HRPconjugated secondary antibody (1:2000; Sigma-Aldrich, USA) for $1 \mathrm{~h}$ at room temperature. After washing with TBST, the protein bands were visualized using an ECL Western blotting kit (Millipore, USA). Densitometry was analyzed using AlphaEaseFC software.

\section{Statistics}

Data from mechanical allodynia (threshold bending force in grams) tests were analyzed using repeated-measure 2-way analysis of variance (ANOVA) as described previously [35]. Testing time points detected overall differences between treatment groups. The data were also examined using 2-way ANOVA across treatment groups to examine overall differences between testing time points. When significant main effects were observed, post hoc Newman-Keuls tests were performed to determine the source(s) of differences. The experimenters were blinded to the treatment conditions. All results are expressed as the means \pm SE. Differences were considered statistically significant at the level of $p=0.05$. For all other experiments, differences were compared using one-way ANOVA followed by post hoc Newman-Keuls tests in SPSS 17.0 (SPSS Inc., Chicago, IL, USA).

\section{Results}

\section{NR2A and NR2B Antagonists Prevented and Reversed SNI-Induced Allodynia}

To determine whether blockade of synaptic and extrasynaptic NMDARs prevented the development of pain behaviors after SNI, the NR2A-selective antagonist NVP-AAM077 (4 nmol) and the NR2B-selective antagonist Ro25-6981 (20 nmol) were administered intrathecally once daily for 14 days beginning immediately after SNI or sham operation. Behavioral tests on the hind paws were performed $30 \mathrm{~min}$ after administration on days $1,3,5,7,10$, and 14. NVP-AAM077 and Ro25-6981 prevented the development of mechanical allodynia of the hind paw ipsilateral to SNI compared to the vehicle group (Fig. 1a $n=6 ; P<0.05$ ). NVP-AAM077 and Ro25-6981 had no effect on mechanical allodynia on the contralateral side in the same rat (Fig. 1b). NVP-AAM077 and Ro25-6981 also reversed established neuropathic pain behaviors in SNI rats. A single intrathecal administration of NVPAAM077 (4 nmol) and Ro25-6981 (20 nmol) attenuated mechanical allodynia on day 14 after SNI 30 min after treatment, and the effect of NVP-AAM077 was maintained for $24 \mathrm{~h}$ (Fig. $1 \mathrm{c} ; n=5 ; P<0.05)$. NVP-AAM077 and Ro25-6981 had no effect on the contralateral side (Fig. 1d). The attenuation effect of NVP-AAM077 and Ro25-6981 was the same as treatment with $10 \mathrm{nmol}$ MK-801, which is a noncompetitive NMDAR antagonist (Fig. 1e, $n=6$ ). These data demonstrated that NR2A and NR2B antagonists prevented and reversed SNIinduced allodynia.

\section{NR2A and NR2B Antagonists Prevented Exogenous Leptin-Mimicked SNI-Induced Behavioral Changes}

Our previous research found that spinal leptin contributed to the pathogenesis of neuropathic pain, and the central effect of leptin was likely related to the activation of NMDARs [34, 35]. Leptin upregulated the expression of spinal NMDAR subunit NR1 and enhanced NMDAR-induced currents in spinal cord lamina II neurons $[34,35]$. The present study further examined whether leptin contributed to the pathogenesis of neuropathic pain by acting on synaptic or extrasynaptic NMDARs.

To determine whether NR2A and NR2B antagonists prevented spinal administration of exogenous leptin-induced mechanical allodynia in naïve rats, different groups of naïve rats received (a) vehicle, (b) $50 \mu \mathrm{g}$ leptin, (c) $50 \mu \mathrm{g}$ leptin plus $4 \mathrm{nmol}$ NVP-AAM077, (d) $50 \mu \mathrm{g}$ leptin plus $20 \mathrm{nmol}$ Ro256981, or (e) 4 nmol NVP-AAM077, and (f) 20 nmol Ro256981 , intrathecally once daily for 7 days. On day 7 , intrathecal leptin induced mechanical allodynia in naïve rats similar to SNI rats, and coadministration with 4 nmol NVP-AAM077 or 20 nmol Ro25-6981 prevented this effect (Fig. 2a; $n=5$; $P<0.01)$. NVP-AAM077 and Ro25-6981 alone did not change the baseline nociceptive threshold (Fig. $2 \mathrm{~b} ; n=6$ ). These data showed that NR2A and NR2B antagonists prevented leptin-induced mechanical allodynia.

\section{Leptin Enhanced NR2B- But Not NR2A-Mediated Currents in Dissociated Lamina II Neurons in Naïve Rats}

Our previous results showed that leptin enhanced NMDARmediated currents in dissociated substantia gelatinosa (lamina II) neurons of the spinal cord dorsal horn $[34,35]$. We chose lamina II neurons because finely myelinated (A $\delta$ ) and unmyelinated (C) primary nociceptive afferent fibers project to this spinal region [50, 51]. The present study further examined whether leptin enhanced synaptic or extrasynaptic NMDARmediated currents in lamina II neurons in naïve rats.

NMDAR-mediated currents were evoked by ejecting $50 \mu \mathrm{M}$ NMDA plus $10 \mu \mathrm{M}$ glycine in $\mathrm{Mg}^{2+}$-free ACSF for $30 \mathrm{~s}$ at a holding potential of $-70 \mathrm{mV}$ [35]. It was difficult to directly measure synaptic or extrasynaptic NMDAR-mediated currents using whole-cell recording. Therefore, we administered the NR2A-selective antagonist NVP-AAM077 in ACSF to block NR2A-mediated currents and obtain extrasynaptic NMDAR-mediated currents because synaptic NMDARs primarily comprise NR1/NR2A in the spinal cord. Similarly, we 

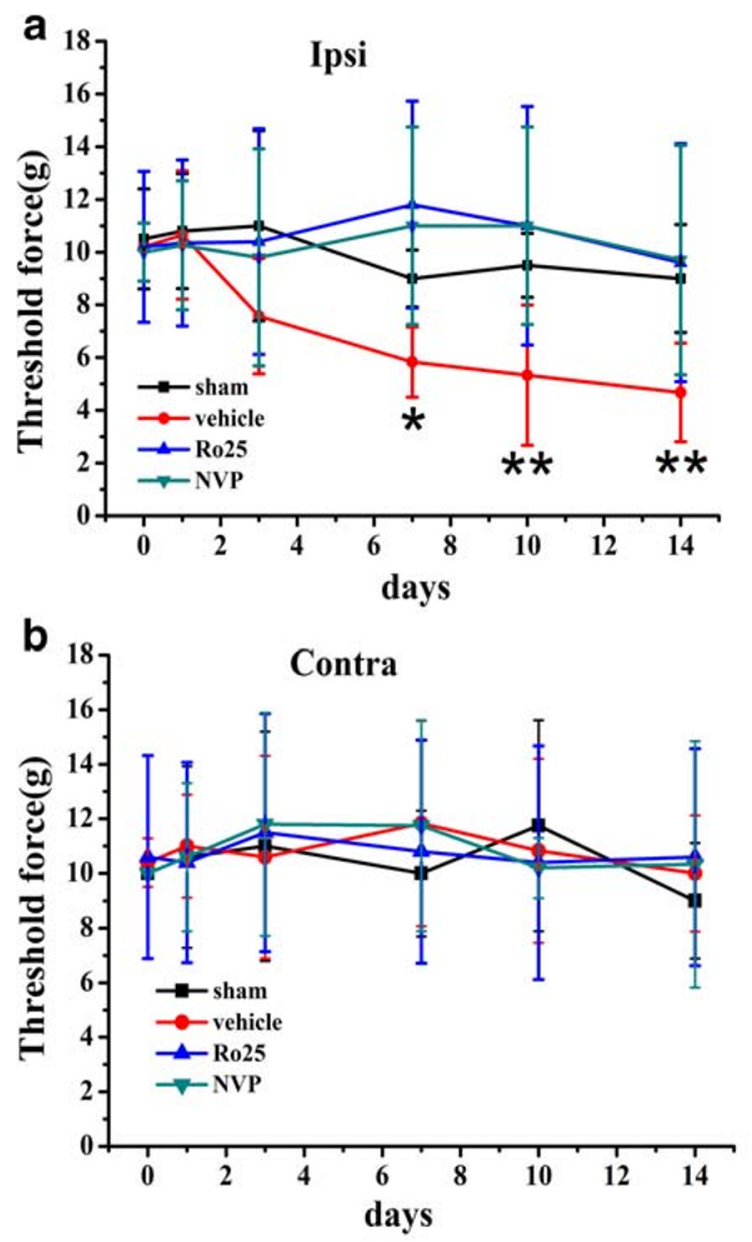

Fig. 1 NR2A and NR2B antagonists prevented and reversed mechanical allodynia in rats with SNI. a The threshold force of SNI-induced mechanical allodynia on the ipsilateral hind paw was significantly decreased on day 7 and continued until day 14. Intrathecal treatment with the NR2Aselective antagonist NVP-AAM077 (4 nmol) and the NR2B-selective antagonist Ro25-6981 (20 nmol) once daily for 14 days prevented the development of mechanical allodynia on the hind paw ipsilateral to SNI on days $3,5,7,10$, and 14. $\mathbf{c}$ A single intrathecal administration of NVPAAM077 (4 nmol) and Ro25-6981 (20 nmol) on day 14 attenuated

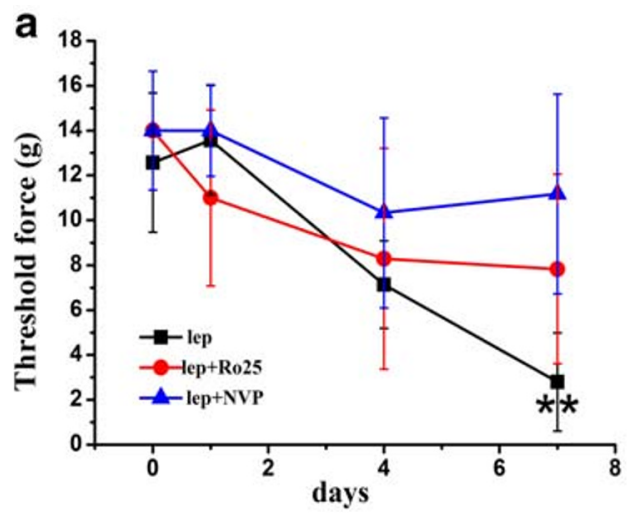

Fig. 2 NR2A and NR2B antagonists prevented exogenous leptininduced mechanical allodynia. a Intrathecal leptin $(50 \mu \mathrm{g})$ treatment in naïve rats, given once daily for 7 days, induced mechanical allodynia on

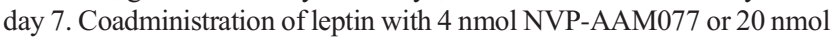
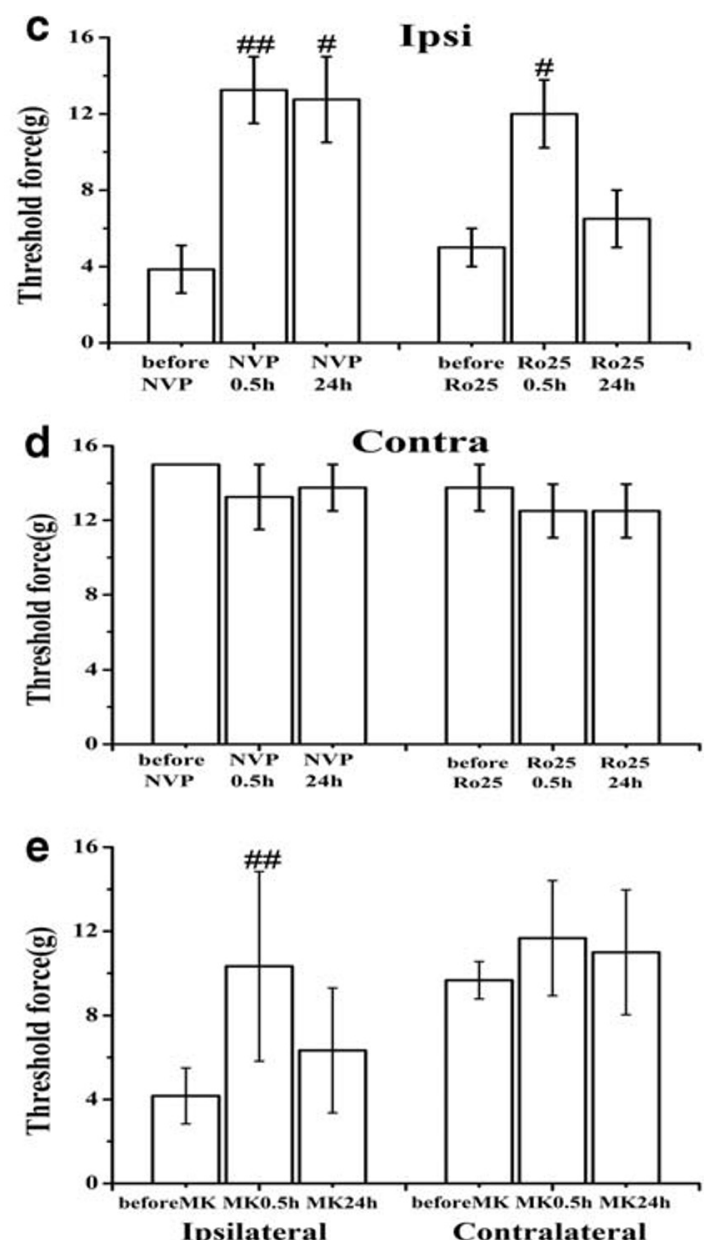

mechanical allodynia at $30 \mathrm{~min}$ after the treatment, and the effect of NVP-AAM077 was maintained for 24 h. b, d NVP-AAM077 and Ro25-6981 did not change the mechanical nociceptive threshold of the contralateral hind paw in the same rat. e A single intrathecal administration of $10 \mathrm{nmol}$ MK-801 on day 14 reversed SNI-induced mechanical allodynia $30 \mathrm{~min}$ after the treatment. NVP, NVP-AAM077; Ro25, Ro256981; MK, MK-801. Data are shown as the means \pm SE. $* P<0.05$, ${ }^{*} * P<0.01$ versus vehicle. ${ }^{\#} P<0.05,{ }^{\# \#} P<0.01$ versus before the single intrathecal treatment

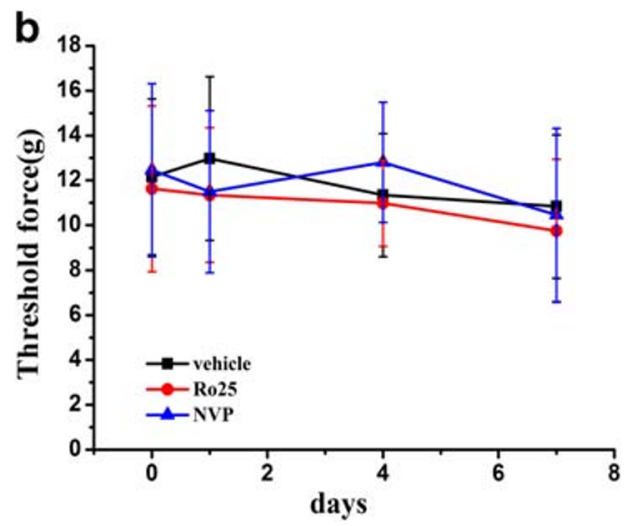

Ro25-6981 attenuated the behavioral changes $(n=5)$. b NVP-AAM077 and Ro25-6981 alone did not change the baseline nociceptive threshold $(n=6)$. lep, leptin; NVP, NVP-AAM077; Ro25, Ro25-6981. Data are shown as the means \pm SE. $* * P<0.01$ versus day 0 
obtained synaptic NMDAR-mediated currents via the addition of the NR2B-selective antagonist Ro25-6981 to ACSF to block extrasynaptic NMDAR-mediated currents.

The amplitude of NMDAR-mediated currents ranged from 50 to $500 \mathrm{pA}$ with a mean of $169.47 \pm 18.39 \mathrm{pA}$ (Fig. 3). Exposure to $0.4 \mu \mathrm{M}$ NVP-AAM077 for $5 \mathrm{~min}$ reduced less than half of NMDAR-mediated currents. Subsequent exposure to $0.4 \mu \mathrm{M}$ NVP-AAM077 plus $1 \mu \mathrm{M}$ Ro25-6981 for 5 min almost completely blocked NMDAR-mediated currents (Fig. 3a). These data suggested that the whole-cell NMDARmediated currents comprised NR2A- and NR2B-mediated components.

After treatment with $1 \mu \mathrm{M}$ Ro25-6981 to block NR2Bmediated currents, the application of $100 \mathrm{nM}$ leptin to ACSF for $5 \mathrm{~min}$ did not change the NR2A-mediated currents (Fig. $3 \mathrm{~b}, \mathrm{~d})$. In contrast, the application of $100 \mathrm{nM}$ leptin to ACSF for 5 min significantly enhanced the currents after blockade with $0.4 \mu \mathrm{M}$ NVP-AAM077 (Fig. 3c, d $P<0.05$ ). These results suggested that leptin enhanced extrasynaptic, but not synaptic, NMDAR-mediated currents in dissociated lamina II neurons.

\section{Leptin Enhanced NR2B, But Not NR2A, Expression in Cultured DRG Neurons}

The DRG convey sensory information from the periphery to the CNS and may be damaged in peripheral sensory neuropathic pain [52]. To confirm the relationship of leptin with synaptic or extrasynaptic NMDARs in neuropathic pain, we used an in vitro dissociated DRG neuron culture from adult (postnatal 4- to 6-week-old) naïve rats [47]. DRG neuron culture was established for $72 \mathrm{~h}$, and the culture medium was replaced with a medium containing leptin or vehicle for $72 \mathrm{~h}$ [34]. Immunohistochemistry results showed that exposure to

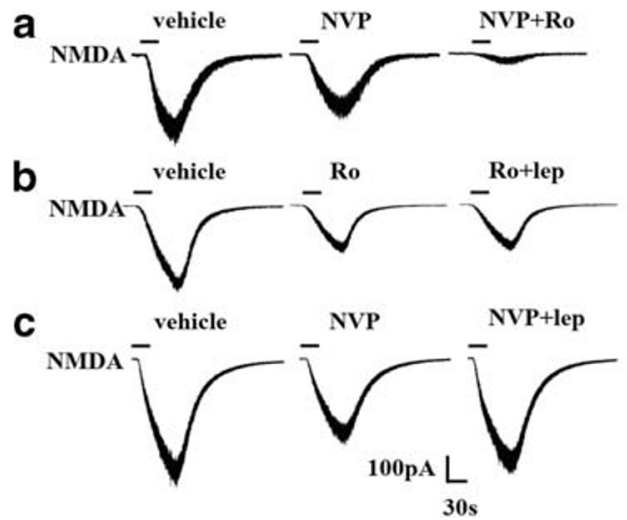

Fig. 3 Leptin enhancement of NR2B- but not NR2A-mediated currents in dissociated lamina II neurons in naïve rats. a Treatment with the NR2A-selective antagonist NVP-AAM077 $(0.4 \mu \mathrm{M})$ plus the NR2Bselective antagonist Ro25-6981 $(1 \mu \mathrm{M})$ blocked NMDAR-mediated currents $(n=8)$. b Exposure to leptin $(100 \mathrm{nM})$ for $5 \mathrm{~min}$ did not change NMDAR-mediated currents after blockade with Ro25-6981 $(1 \mu \mathrm{M})(n=$ exogenous leptin upregulated the expression of NR2B in DRG neuron culture in a dose-dependent manner, with the maximal enhancement occurring at $2 \mathrm{ng} / \mathrm{ml}$ leptin (2 ng/ml $>20 \mathrm{ng} / \mathrm{ml}>0.2 \mathrm{ng} / \mathrm{ml}=$ vehicle. Figure $4 \mathrm{a}, n=3$, $P<0.05)$. This concentration $(2 \mathrm{ng} / \mathrm{ml})$ of leptin was used in subsequent culture experiments. Immunohistochemistry results and western blot results showed that the addition of $1 \mu \mathrm{M}$ Ro25-6981 to the leptin (2 ng/ml) culture medium for $72 \mathrm{~h}$ significantly diminished the upregulation of NR2B expression by leptin, whereas $1 \mu \mathrm{M}$ Ro25-6981 alone did not change the baseline expression of NR2B (Fig. 4a, c, d, $n=3$ ). However, $2 \mathrm{ng} / \mathrm{ml}$ leptin did not significantly upregulate NR2A expression (Fig. 4b, e, f, $n=3$ ). These data showed that leptin significantly upregulated NR2B, but not NR2A, expression in cultured DRG neurons.

\section{Leptin Enhanced nNOS Expression in Cultured DRG Neurons}

To examine the cellular mechanisms underlying the spinal leptin effect on neuropathic pain, we determined whether the expression of nNOS was changed after exogenous leptin treatment because nNOS is a downstream target following NMDAR activation $[19,22,41,42]$. The inclusion of leptin ( $2 \mathrm{ng} / \mathrm{ml}$ ) in culture medium for $72 \mathrm{~h}$ significantly upregulated nNOS expression in cultured DRG neurons, as revealed by immunohistochemistry (Fig. 5a) and Western blot (Fig. 5b, c). Coadministration of Ro25-6981 (1 $\mu \mathrm{M})$, but not NVPAAM077 $(0.4 \mu \mathrm{M})$, with leptin effectively prevented the leptin-induced upregulation of nNOS expression. Ro25$6981(1 \mu \mathrm{M})$ and NVP-AAM077 $(0.4 \mu \mathrm{M})$ alone did not change the baseline nNOS expression. These results suggested that leptin enhanced nNOS expression via NR2B activation.

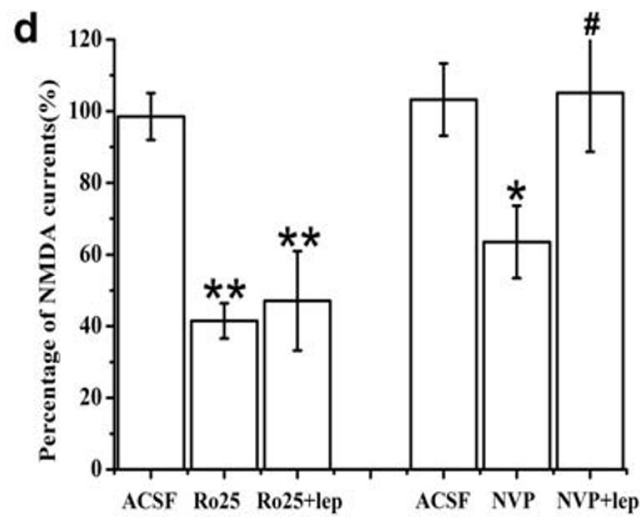

10). c Exposure to leptin (100 nM) for 5 min enhanced NMDARmediated currents after inhibition by $0.4 \mu \mathrm{M}$ NVP-AAM077 $(n=9)$. d Histograms showing the effect of leptin on NMDAR-mediated currents after inhibition by NVP-AAM077 or Ro25-6981. Data are shown as the means \pm SE. lep, leptin; NVP, NVP-AAM077; Ro, Ro25-6981. $* P<0.05,{ }^{*} * P<0.01$ vs. vehicle; ${ }^{*} P<0.05$ vs NVP 


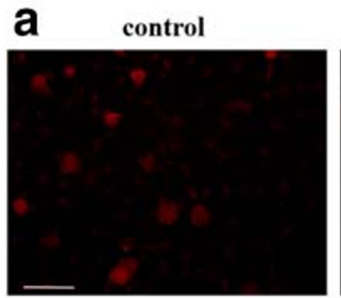

leptin $0.2 \mathrm{ng}$
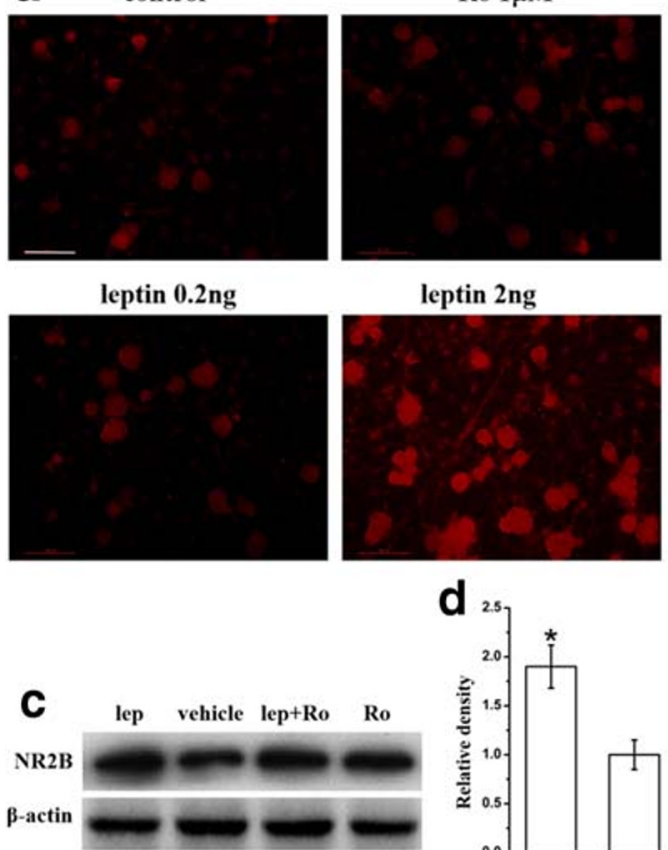

leptin 2ng
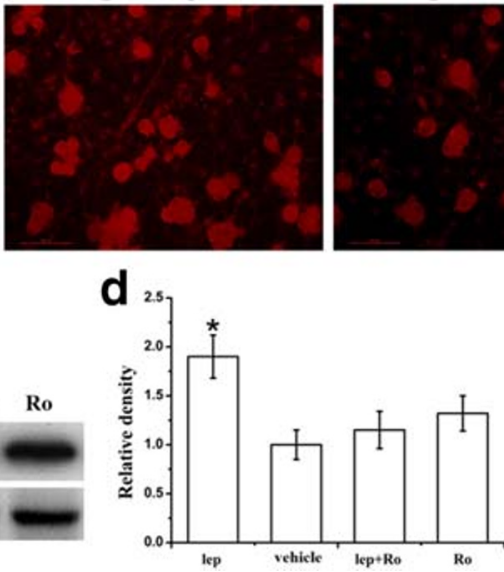

Fig. 4 Leptin enhancement of NR2B, but not NR2A, expression in cultured DRG neurons. a Immunohistochemistry results showed that administration of leptin in culture medium for $72 \mathrm{~h}$ upregulated NR2B expression in a dose-dependent manner $(2 \mathrm{ng} / \mathrm{ml}$ leptin had the maximal enhancement effect), and cotreatment with $1 \mu \mathrm{M}$ Ro25-6981 diminished the upregulation. b Leptin at $2 \mathrm{ng} / \mathrm{ml}$ slightly enhanced NR2A expression, which was attenuated by $0.4 \mu \mathrm{M}$ NVP-AAM077. $\mathbf{c}-\mathbf{f}$ Western blot results b
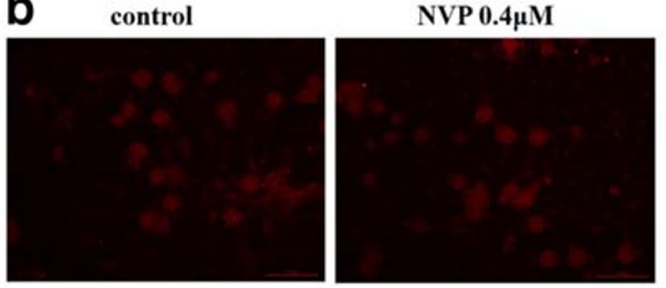

leptin 2ng

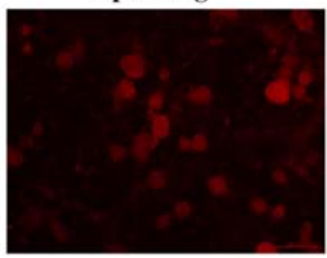

leptin 2ng+NVP $0.4 \mu \mathrm{M}$

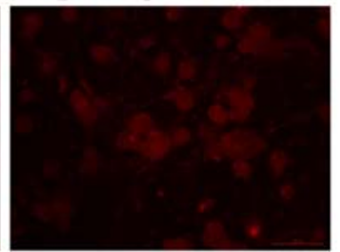

f
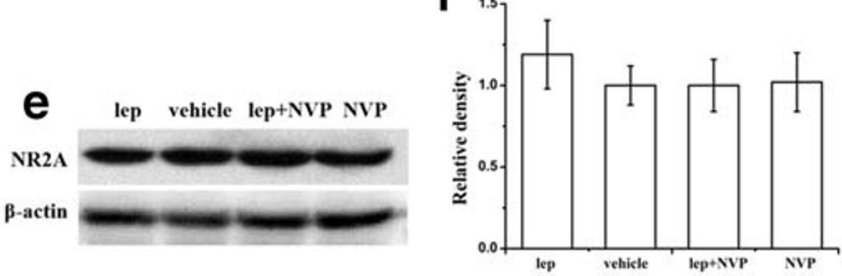

showed that administration of leptin $(2 \mathrm{ng} / \mathrm{ml})$ to culture medium for $72 \mathrm{~h}$ significantly upregulated NR2B expression $(\mathbf{c}, \mathbf{d})$ but not NR2A expression $(\mathbf{e}, \mathbf{f})$ in cultured DRG neurons. The NR2B upregulation was blocked by $1 \mu \mathrm{M}$ Ro25-6981 (c, d). Neither $1 \mu \mathrm{M}$ Ro25-6981 nor 0.4 $\mu \mathrm{M}$ NVPAAM077 alone changed the baseline expression of NR2B or NR2A. lep, leptin; NVP, NVP-AAM077; Ro, Ro25-6981. $n=3$. Scale bar, $50 \mu \mathrm{m}$. $* P<0.05$ vs vehicle

Fig. 5 Leptin-mediated enhancement of nNOS expression was blocked by an NR2B antagonist.

Immunohistochemistry (a) and Western blot (b and $\mathbf{c}$ ) results showed that administration of leptin $(2 \mathrm{ng} / \mathrm{ml})$ to culture medium for $72 \mathrm{~h}$ significantly upregulated nNOS expression in cultured DRG neurons. The upregulation of nNOS expression by leptin was significantly prevented by coapplication of the NR2B antagonist Ro25-6981

$(1 \mu \mathrm{M})$ and slightly attenuated by the NR2A antagonist NVPAAM077 (0.4 $\mu \mathrm{M})$. Ro25-6981 $(1 \mu \mathrm{M})$ and NVP-AAM077 $(0.4 \mu \mathrm{M})$ alone did not change baseline nNOS expression. Lep, leptin; NVP, NVP-AAM077; Ro, Ro25-6981. $n=3$. Scale bar, $50 \mu \mathrm{m} . * * P<0.01$ vs vehicle; ${ }^{\#} P<0.05$ vs leptin
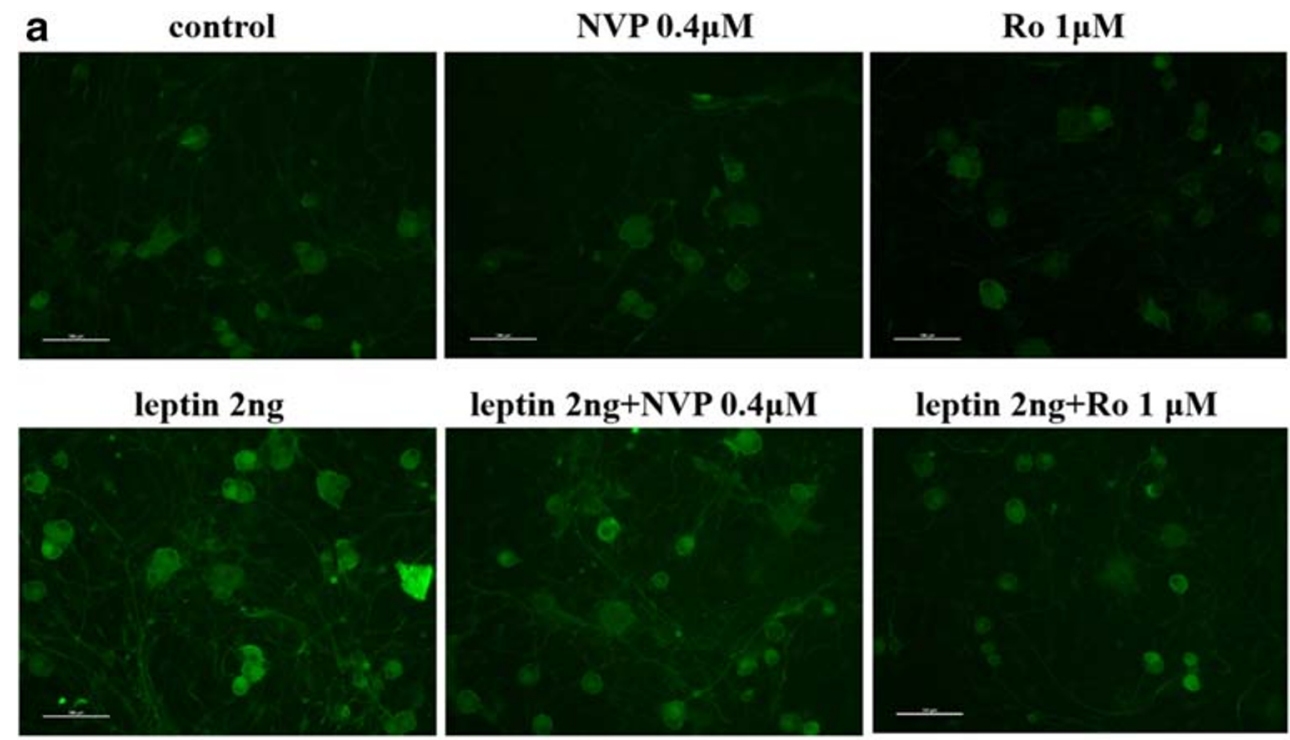

leptin 2ng+NVP $0.4 \mu M$
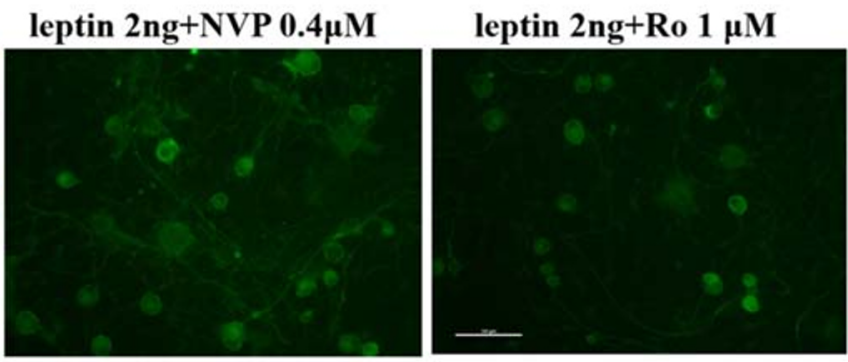

b

lep vehicle lep+NVP lep+Ro NVP Ro nNOS $\beta$-actin

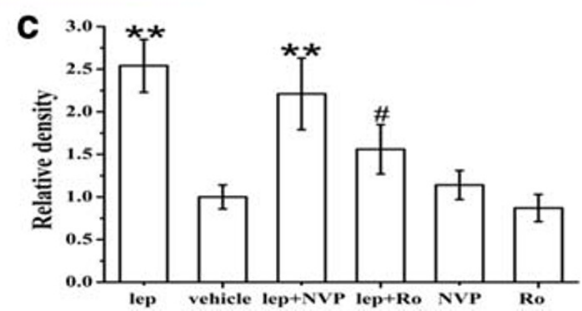




\section{Discussion}

The present study demonstrated the following results: (1) the intrathecal administration of the NR2A-selective antagonist NVP-AAM077 and the NR2B-selective antagonist Ro256981 prevented and reversed SNI-induced allodynia; (2) administration of exogenous leptin mimicked SNI-induced allodynia, which was also prevented by NR2A and NR2B antagonists; (3) leptin enhanced spinal NR2B- but not NR2A-mediated currents in naïve lamina II neurons; and (4) leptin upregulated the expression of NR2B, but not NR2A, and nNOS in cultured DRG cells, which were blocked by the NR2B antagonist Ro25-6981. These data suggested that the contribution of leptin to the pathogenesis of neuropathic pain was related to NR2B-based extrasynaptic NMDARs and activation of nNOS, as the downstream factor of NMDAR. However, the relationship between NR2A-based synaptic NMDARs and the effect of leptin on neuropathic pain needs further investigation.

Leptin is a $16-\mathrm{kDa}$ adipocytokine that is primarily produced by white adipose tissue, and it is well-known for its role in metabolic regulation and obesity [28-31]. Mounting evidence indicates that leptin has broad roles in the regulation of neuronal functions $[32,33]$. Leptin was recently demonstrated to contribute to the pathogenesis of neuropathic pain [34-36, $53,54]$. Leptin and leptin receptors $(\mathrm{Ob}-\mathrm{Rb})$ are expressed in the spinal cord dorsal horn and DRG and are upregulated after nerve injury [34, 54-57]. Leptin-deficient animals or leptin receptor (Ob-Rb)-deficient animals showed an absence of nerve injury-induced neuropathic pain behaviors, which were reversed by exogenous leptin administration [34, 36, 53, 58]. Chronic administration of exogenous leptin induced thermal hyperalgesia and mechanical allodynia in naïve rats [34, 35]. Treatment with a leptin antibody abolished nerve injury or exogenous leptin administration-induced neuropathic pain behaviors $[34,36]$. Our data demonstrated that exogenous leptin administration mimicked SNI-induced mechanical allodynia (Fig. 2a), which further supports the contribution of leptin to neuropathic pain.

NMDARs are one of three ligand-gated ion channels activated by the excitatory transmitter glutamate. Functional NMDARs are a heteromeric complex primarily comprising two NR1 subunits and two NR2 subunits. The different NR2 subunits endow NMDARs with different roles. NR2A predominates at synaptic sites and plays a role in LTP. NR2B is mostly expressed at extrasynaptic sites and is involved in LTD $[5,6,13,14]$. In ischemia- and brain trauma-induced neuronal injury, NR2A activation promotes neuronal survival, and NR2B activation results in neuronal death [15-18].

NMDARs play a crucial role in the mechanisms of peripheral and central sensitization [1-4]. Our previous studies indicated a possible functional link between leptin and NMDARs in neuropathic pain $[34,35]$. The NMDAR antagonist MK-
801 attenuated the upregulation of NMDAR subunit NR1 expression and neuropathic pain behavior induced by the spinal administration of exogenous leptin. Leptin enhanced NMDAR-mediated currents in rat spinal cord slices and enhanced spinal NMDA-induced spontaneous BSL behaviors, which are a behavioral indication of spinal excitation.

NR2B plays an important role in the development of neuropathic pain. NR2B is upregulated in the spinal dorsal horn and DRG after peripheral nerve injury [7, 24, 48, 59]. Several lines of evidence showed that phosphorylation of NR2B, especially at Tyr1472, was upregulated after nerve injury, which suggests that spinal NR2B phosphorylation plays a crucial role in central sensitization after nerve injury $[19,37$, 60-63]. NR2B special antagonists effectively relieved pain behaviors without causing motor dysfunction [20-23, 48].

The important role of NR2B in the development of neuropathic pain may be due to the impairment of glutamate uptake. Peripheral nerve injury decreased glutamate transporter protein expression and glutamate uptake activity in the spinal dorsal horn [64-66]. Impaired glutamate uptake caused glutamate spillover outside active synapses and increased the open probability of NMDA channels, which led to activation of extrasynaptic NMDA receptors $[65,67,68]$. Nie and Weng demonstrated that blockade of glutamate transporters resulted in an increased proportion of NR2B subunit activation induced by peripheral input, and stronger afferent input further augmented this increase [69]. These data suggested that impairment of glutamate uptake led to the excessive activation of extrasynaptic glutamate receptors, which is a crucial process related to the initiation and maintenance of neuropathic pain.

Our results support a critical relationship between leptin and NR2B-based extrasynaptic NMDARs in neuropathic pain based on the following results: (a) intrathecal administration of the NR2B-selective antagonist Ro25-6981 prevented and reversed SNI-induced allodynia; (b) spinal administration of leptin mimicked SNI-induced allodynia, which was also prevented by Ro25-6981; (c) mechanistic studies showed that leptin upregulated NR2B expression, which was blocked by Ro25-6981, in cultured DRG cells; and (d) leptin enhanced NR2B-mediated currents in spinal cord lamina II neurons. These results indicated that leptin contributed to neuropathic pain via extrasynaptic NMDAR activation. We will further investigate whether leptin directly impairs glutamate uptake and causes glutamate spillover outside of the active synapses, leading to the excessive activation of extrasynaptic NMDA receptors in neuropathic pain.

Whether NR2A is involved in neuropathic pain is controversial. Some studies showed that NR2A expression decreased or did not change in the superficial dorsal horn after nerve injury $[7,24,70,71]$. Abe et al. found that NR2Adeficient mice developed neuropathic pain similar to wildtype mice after transection of spinal nerve L5 [19]. These data suggest that NR2A is not involved in the process of 
neuropathic pain. However, other studies demonstrated that the expression level of NR2A increased significantly in the dorsal horn and DRG after nerve injury [25, 27]. Nozaki et al. found that zinc alleviated pain via high-affinity binding to NR2A [26]. These results suggest that the role of NR2A in neuropathic pain is complicated.

The present study found that (a) intrathecal administration of the NR2A-selective antagonist NVP-AAM077 prevented and reversed SNI-induced allodynia, and (b) treatment with NVP-AAM077 also prevented spinal leptin-induced allodynia. However, leptin did not upregulate NR2A expression in cultured DRG cells, and leptin did not enhance NR2Amediated currents in spinal cord slices. According to these results, whether NR2A is involved in the contribution of leptin to neuropathic pain is not clear.

Three types of NOS, neuronal NOS (nNOS), endothelial NOS (eNOS), and inducible NOS (iNOS), exist in the central nervous system. nNOS plays an important role in the development and maintenance of neuropathic pain. The expression and activation of nNOS in the spinal cord dorsal horn and DRG are increased after nerve injury, and intrathecal injection of a nonselective NOS inhibitor or selective nNOS inhibitor significantly alleviated pain behavior [22, 39, 72, 73]. Overexpression of nNOS decreased the pain threshold in mice with partial sciatic nerve ligation [40], and nerve injuryinduced mechanical allodynia was significantly reduced in nNOS gene knockout mice [38].

nNOS is involved in neuropathic pain as a downstream target of NR2B. NR2B is concentrated in the postsynaptic density (PSD), where it integrates dynamically with cytoskeletal proteins and signal transduction factors, such as nNOS, and hence it participates in nociceptive signal transduction [22, 41]. In some pain models, not only nNOS activity and expression was increased, NR2B expression or NR2B phosphorylation at Tyr1472 in the spinal cord dorsal horn or DRG was also increased [19, 39, 42, 74, 75], and NR2B antagonists reversibly reduced nNOS activation to basal levels by $[19,22,76]$.

Our data showed that leptin upregulated the expression of NR2B and nNOS in cultured DRG cells, and the NR2Bselective antagonist Ro25-6981 blocked this upregulation (Fig. 4a, Fig. 5). These results and the aforementioned results suggested, for the first time, that the contribution of leptin to the pathogenesis of neuropathic pain was related to the NR2Bbased extrasynaptic NMDAR-nNOS pathway. We hypothesized that spinal leptin impairs glutamate uptake after nerve injury. The impairment of glutamate uptake causes glutamate spillover outside of the active synapses, which leads to excessive activation of extrasynaptic NMDAR. Extrasynaptic NMDARs directly interact with nNOS in PSD via the PSD95 scaffold protein, and the activation of extrasynaptic NMDARs increases nNOS activation and nitric oxide (NO) production, which drive nociceptive signal transduction and central sensitization. Our data support extrasynaptic
NMDARs as a new target for new pharmacological interventions for neuropathic pain.

Funding This work was supported by the National Natural Science Foundation of China (No. 31100806, 81771484 and 82073340) and the Natural Science Foundation of Guangdong Province, China (No. 2018A030313835) and the Program for Changjiang Scholars and Innovative Research Team in University (No. IRT_16R37).

\section{Compliance with Ethical Standards}

Conflict of Interest The authors declare that they have no conflict of interest.

Open Access This article is licensed under a Creative Commons Attribution 4.0 International License, which permits use, sharing, adaptation, distribution and reproduction in any medium or format, as long as you give appropriate credit to the original author(s) and the source, provide a link to the Creative Commons licence, and indicate if changes were made. The images or other third party material in this article are included in the article's Creative Commons licence, unless indicated otherwise in a credit line to the material. If material is not included in the article's Creative Commons licence and your intended use is not permitted by statutory regulation or exceeds the permitted use, you will need to obtain permission directly from the copyright holder. To view a copy of this licence, visit http://creativecommons.org/licenses/by/4.0/.

\section{References}

1. D'Mello R, Dickenson AH (2008) Spinal cord mechanisms of pain. Br J Anaesth 101(1):8-16

2. Mao J, Price DD, Hayes RL, Lu J, Mayer DJ (1992) Differential roles of NMDA and non-NMDA receptor activation in induction and maintenance of thermal hyperalgesia in rats with painful peripheral mononeuropathy. Brain Res 598(1-2):271-278

3. Petrenko AB, Yamakura T, Baba H, Shimoji K (2003) The role of $\mathrm{N}$-methyl-D-aspartate (NMDA) receptors in pain: a review. Anesth Analg 97(4):1108-1116

4. Woolf CJ, Thompson SW (1991) The induction and maintenance of central sensitization is dependent on N-methyl-D-aspartic acid receptor activation; implications for the treatment of post-injury pain hypersensitivity states. Pain 44(3):293-299

5. Stocca G, Vicini S (1998) Increased contribution of NR2A subunit to synaptic NMDA receptors in developing rat cortical neurons. J Physiol 507(Pt 1):13-24

6. Tovar KR, Westbrook GL (1999) The incorporation of NMDA receptors with a distinct subunit composition at nascent hippocampal synapses in vitro. J Neurosci 19(10):4180-4188

7. Karlsson U, Sjodin J, Angeby Moller K, Johansson S, Wikstrom L, Nasstrom J (2002) Glutamate-induced currents reveal three functionally distinct NMDA receptor populations in rat dorsal horn effects of peripheral nerve lesion and inflammation. Neuroscience 112(4):861-868

8. Marvizon JC, McRoberts JA, Ennes HS, Song B, Wang X, Jinton L, Corneliussen B, Mayer EA (2002) Two N-methyl-D-aspartate receptors in rat dorsal root ganglia with different subunit composition and localization. J Comp Neurol 446(4):325-341

9. Momiyama A (2000) Distinct synaptic and extrasynaptic NMDA receptors identified in dorsal horn neurones of the adult rat spinal cord. J Physiol 523(Pt 3):621-628 
10. Nagy GG, Watanabe M, Fukaya M, Todd AJ (2004) Synaptic distribution of the NR1, NR2A and NR2B subunits of the N-methyl-daspartate receptor in the rat lumbar spinal cord revealed with an antigen-unmasking technique. Eur J Neurosci 20(12):3301-3312

11. Kopke AK, Bonk I, Sydow S, Menke H, Spiess J (1993) Characterization of the NR1, NR2A, and NR2C receptor proteins. Protein Sci 2(12):2066-2076

12. Llansola M, Sanchez-Perez A, Cauli O, Felipo V (2005) Modulation of NMDA receptors in the cerebellum. 1. Properties of the NMDA receptor that modulate its function. Cerebellum 4(3): 154-161

13. Liu L, Wong TP, Pozza MF, Lingenhoehl K, Wang Y, Sheng M, Auberson YP, Wang YT (2004) Role of NMDA receptor subtypes in governing the direction of hippocampal synaptic plasticity. Science 304(5673):1021-1024

14. Massey PV, Johnson BE, Moult PR, Auberson YP, Brown MW, Molnar E, Collingridge GL, Bashir ZI (2004) Differential roles of NR2A and NR2B-containing NMDA receptors in cortical longterm potentiation and long-term depression. J Neurosci 24(36): 7821-7828

15. Chen M, Lu TJ, Chen XJ, Zhou Y, Chen Q, Feng XY, Xu L, Duan WH et al (2008) Differential roles of NMDA receptor subtypes in ischemic neuronal cell death and ischemic tolerance. Stroke 39(11): 3042-3048

16. Hardingham GE, Fukunaga Y, Bading H (2002) Extrasynaptic NMDARs oppose synaptic NMDARs by triggering CREB shutoff and cell death pathways. Nat Neurosci 5(5):405-414

17. Liu Y, Wong TP, Aarts M, Rooyakkers A, Liu L, Lai TW, Wu DC, $\mathrm{Lu} J$ et al (2007) NMDA receptor subunits have differential roles in mediating excitotoxic neuronal death both in vitro and in vivo. $\mathrm{J}$ Neurosci 27(11):2846-2857

18. Sattler R, Xiong Z, Lu WY, MacDonald JF, Tymianski M (2000) Distinct roles of synaptic and extrasynaptic NMDA receptors in excitotoxicity. J Neurosci 20(1):22-33

19. Abe T, Matsumura S, Katano T, Mabuchi T, Takagi K, Xu L, Yamamoto A, Hattori K et al (2005) Fyn kinase-mediated phosphorylation of NMDA receptor NR2B subunit at Tyr1472 is essential for maintenance of neuropathic pain. Eur J Neurosci 22(6): 1445-1454

20. Chizh BA, Headley PM, Tzschentke TM (2001) NMDA receptor antagonists as analgesics: Focus on the NR2B subtype. Trends Pharmacol Sci 22(12):636-642

21. Huang LE, Guo SH, Thitiseranee L, Yang Y, Zhou YF, Yao YX (2018) N-methyl D-aspartate receptor subtype 2B antagonist, Ro 25-6981, attenuates neuropathic pain by inhibiting postsynaptic density 95 expression. Sci Rep 8(1):7848

22. Mihara Y, Egashira N, Sada H, Kawashiri T, Ushio S, Yano T, Ikesue H, Oishi R (2011) Involvement of spinal NR2B-containing NMDA receptors in oxaliplatin-induced mechanical allodynia in rats. Mol Pain 7:8

23. Qu XX, Cai J, Li MJ, Chi YN, Liao FF, Liu FY, Wan Y, Han JS et al (2009) Role of the spinal cord NR2B-containing NMDA receptors in the development of neuropathic pain. Exp Neurol 215(2): 298-307

24. Wilson JA, Garry EM, Anderson HA, Rosie R, Colvin LA, Mitchell R, Fleetwood-Walker SM (2005) NMDA receptor antagonist treatment at the time of nerve injury prevents injury-induced changes in spinal NR1 and NR2B subunit expression and increases the sensitivity of residual pain behaviours to subsequently administered NMDA receptor antagonists. Pain 117(3):421-432

25. Labombarda F, Coronel MF, Villar MJ, Nicola AF, Gonzalez SL (2008) Neuropathic pain and temporal expression of preprodynorphin, protein kinase $\mathrm{C}$ and $\mathrm{N}$-methyl-D-aspartate receptor subunits after spinal cord injury. Neurosci Lett 447(2-3): 115-119
26. Nozaki C, Vergnano AM, Filliol D, Ouagazzal AM, Le Goff A, Carvalho S, Reiss D, Gaveriaux-Ruff C et al (2011) Zinc alleviates pain through high-affinity binding to the NMDA receptor NR2A subunit. Nat Neurosci 14(8):1017-1022

27. Yang L, Gu X, Zhang W, Zhang J, Ma Z (2014) Cdk5 inhibitor roscovitine alleviates neuropathic pain in the dorsal root ganglia by downregulating N-methyl-D-aspartate receptor subunit 2A. Neurol Sci 35(9): 1365-1371

28. Ahima RS, Qi Y, Singhal NS, Jackson MB, Scherer PE (2006) Brain adipocytokine action and metabolic regulation. Diabetes 55(Suppl 2):S145-S154

29. Elmquist JK, Maratos-Flier E, Saper CB, Flier JS (1998) Unraveling the central nervous system pathways underlying responses to leptin. Nat Neurosci 1(6):445-450

30. Schwartz MW, Woods SC, Porte D Jr, Seeley RJ, Baskin DG (2000) Central nervous system control of food intake. Nature 404(6778):661-671

31. Zhang Y, Proenca R, Maffei M, Barone M, Leopold L, Friedman JM (1994) Positional cloning of the mouse obese gene and its human homologue. Nature 372(6505):425-432

32. Harvey J (2007) Leptin: a diverse regulator of neuronal function. J Neurochem 100(2):307-313

33. Myers MG Jr (2004) Leptin receptor signaling and the regulation of mammalian physiology. Recent Prog Horm Res 59:287-304

34. Lim G, Wang S, Zhang Y, Tian Y, Mao J (2009) Spinal leptin contributes to the pathogenesis of neuropathic pain in rodents. $\mathrm{J}$ Clin Invest 119(2):295-304

35. Tian Y, Wang S, Ma Y, Lim G, Kim H, Mao J (2011) Leptin enhances NMDA-induced spinal excitation in rats: a functional link between adipocytokine and neuropathic pain. Pain 152(6):12631271

36. Maeda T, Kiguchi N, Kobayashi Y, Ikuta T, Ozaki M, Kishioka S (2009) Leptin derived from adipocytes in injured peripheral nerves facilitates development of neuropathic pain via macrophage stimulation. Proc Natl Acad Sci U S A 106(31):13076-13081

37. Katano T, Nakazawa T, Nakatsuka T, Watanabe M, Yamamoto T, Ito $S$ (2011) Involvement of spinal phosphorylation cascade of Tyr1472-NR2B, Thr286-CaMKII, and Ser831-GluR1 in neuropathic pain. Neuropharmacology 60(4):609-616

38. Guan Y, Yaster M, Raja SN, Tao YX (2007) Genetic knockout and pharmacologic inhibition of neuronal nitric oxide synthase attenuate nerve injury-induced mechanical hypersensitivity in mice. Mol Pain 3:29

39. Mabuchi T, Matsumura S, Okuda-Ashitaka E, Kitano T, Kojima H, Nagano T, Minami T, Ito S (2003) Attenuation of neuropathic pain by the nociceptin/orphanin FQ antagonist JTC- 801 is mediated by inhibition of nitric oxide production. Eur J Neurosci 17(7):1384 1392

40. Tanabe M, Nagatani Y, Saitoh K, Takasu K, Ono H (2009) Pharmacological assessments of nitric oxide synthase isoforms and downstream diversity of NO signaling in the maintenance of thermal and mechanical hypersensitivity after peripheral nerve injury in mice. Neuropharmacology 56(3):702-708

41. Husi H, Grant SG (2001) Proteomics of the nervous system. Trends Neurosci 24(5):259-266

42. Sun Y, Zhang J, Lei Y, Lu C, Hou B, Ma Z, Gu X (2016) Activation of spinal MrgC-Gi-NR2B-nNOS signaling pathway by Mas oncogene-related gene $\mathrm{C}$ receptor agonist bovine adrenal medulla 8-22 attenuates bone cancer pain in mice. Am J Transl Res 8(2): $1144-1154$

43. Decosterd I, Woolf CJ (2000) Spared nerve injury: an animal model of persistent peripheral neuropathic pain. Pain 87(2):149-158

44. Wei XH, Zang Y, Wu CY, Xu JT, Xin WJ, Liu XG (2007) Perisciatic administration of recombinant rat TNF-alpha induces mechanical allodynia via upregulation of TNF-alpha in dorsal root 
ganglia and in spinal dorsal horn: The role of NF-kappa B pathway. Exp Neurol 205(2):471-484

45. Tal M, Bennett GJ (1994) Extra-territorial pain in rats with a peripheral mononeuropathy: mechano-hyperalgesia and mechanoallodynia in the territory of an uninjured nerve. Pain 57(3):375-382

46. Mao J, Sung B, Ji RR, Lim G (2002) Chronic morphine induces downregulation of spinal glutamate transporters: implications in morphine tolerance and abnormal pain sensitivity. J Neurosci 22(18):8312-8323

47. Zang Y, He XH, Xin WJ, Pang RP, Wei XH, Zhou LJ, Li YY, Liu XG (2010) Inhibition of NF-kappaB prevents mechanical allodynia induced by spinal ventral root transection and suppresses the reexpression of Nav1.3 in DRG neurons in vivo and in vitro. Brain Res 1363:151-158

48. Kim Y, Cho HY, Ahn YJ, Kim J, Yoon YW (2012) Effect of NMDA NR2B antagonist on neuropathic pain in two spinal cord injury models. Pain 153(5):1022-1029

49. Tang X, Zhang X, Li S, Chi X, Luo A, Zhao Y (2020) NR2B receptor- and calpain-mediated $\mathrm{KCC} 2$ cleavage resulted in cognitive deficiency exposure to isoflurane. Neurotoxicology 76:75-83

50. Kumazawa T, Perl ER (1978) Excitation of marginal and substantia gelatinosa neurons in the primate spinal cord: Indications of their place in dorsal horn functional organization. J Comp Neurol 177(3): $417-434$

51. Yoshimura M, Jessell TM (1989) Primary afferent-evoked synaptic responses and slow potential generation in rat substantia gelatinosa neurons in vitro. J Neurophysiol 62(1):96-108

52. Ezquerra L, Alguacil LF, Nguyen T, Deuel TF, Silos-Santiago I, Herradon G (2008) Different pattern of pleiotrophin and midkine expression in neuropathic pain: correlation between changes in pleiotrophin gene expression and rat strain differences in neuropathic pain. Growth Factors 26(1):44-48

53. Chang KT, Lin YL, Lin CT, Hong CJ, Tsai MJ, Huang WC, Shih YH, Lee YY et al (2017) Leptin is essential for microglial activation and neuropathic pain after preganglionic cervical root avulsion. Life Sci 187:31-41

54. Li X, Kang L, Li G, Zeng H, Zhang L, Ling X, Dong H, Liang S et al (2013) Intrathecal leptin inhibits expression of the P2X2/3 receptors and alleviates neuropathic pain induced by chronic constriction sciatic nerve injury. Mol Pain 9:65

55. Chang KT, Lin YL, Lin CT, Tsai MJ, Huang WC, Shih YH, Lee YY, Cheng H et al (2017) Data on the expression of leptin and leptin receptor in the dorsal root ganglion and spinal cord after preganglionic cervical root avulsion. Data Brief 15:567-572

56. Chen HP, Fan J, Cui S (2006) Detection and estrogen regulation of leptin receptor expression in rat dorsal root ganglion. Histochem Cell Biol 126(3):363-369

57. Hu F, Cui Y, Guo R, Chen J, Guo R, Shen N, Hua X, Mo L et al (2014) Spinal leptin contributes to the development of morphine antinociceptive tolerance by activating the STAT3-NMDA receptor pathway in rats. Mol Med Rep 10(2):923-930

58. Wright DE, Johnson MS, Arnett MG, Smittkamp SE, Ryals JM (2007) Selective changes in nocifensive behavior despite normal cutaneous axon innervation in leptin receptor-null mutant $(\mathrm{db} / \mathrm{db})$ mice. J Peripher Nerv Syst : JPNS 12(4):250-261

59. Norcini M, Sideris A, Adler SM, Hernandez LA, Zhang J, Blanck TJ, Recio-Pinto E (2016) NR2B expression in rat DRG is differentially regulated following peripheral nerve injuries that lead to transient or sustained stimuli-evoked hypersensitivity. Front Mol Neurosci 9:100

60. Li S, Cai J, Feng ZB, Jin ZR, Liu BH, Zhao HY, Jing HB, Wei TJ et al (2017) BDNF contributes to spinal long-term potentiation and mechanical hypersensitivity via Fyn-mediated phosphorylation of NMDA receptor GluN2B subunit at tyrosine 1472 in rats following spinal nerve ligation. Neurochem Res 42(10):2712-2729
61. Luo XQ, Cai QY, Chen Y, Guo LX, Chen AQ, Wu ZQ, Lin C (2014) Tyrosine phosphorylation of the NR2B subunit of the NMDA receptor in the spinal cord contributes to chronic visceral pain in rats. Brain Res 1542:167-175

62. Qiu S, Chen T, Koga K, Guo YY, Xu H, Song Q, Wang JJ, Descalzi G et al (2013) An increase in synaptic NMDA receptors in the insular cortex contributes to neuropathic pain. Sci Signal 6(275):ra34

63. Unezaki S, Sasaki A, Mabuchi T, Matsumura S, Katano T, Nakazawa T, Nishio N, Andoh T et al (2012) Involvement of Tyr1472 phosphorylation of NMDA receptor NR2B subunit in postherpetic neuralgia in model mice. Mol Pain 8:59

64. Binns BC, Huang Y, Goettl VM, Hackshaw KV, Stephens RL Jr (2005) Glutamate uptake is attenuated in spinal deep dorsal and ventral horn in the rat spinal nerve ligation model. Brain Res 1041(1):38-47

65. Sung B, Lim G, Mao J (2003) Altered expression and uptake activity of spinal glutamate transporters after nerve injury contribute to the pathogenesis of neuropathic pain in rats. J Neurosci 23(7):2899-2910

66. Sung B, Wang S, Zhou B, Lim G, Yang L, Zeng Q, Lim JA, Wang JD et al (2007) Altered spinal arachidonic acid turnover after peripheral nerve injury regulates regional glutamate concentration and neuropathic pain behaviors in rats. Pain 131(1-2):121-131

67. Liaw WJ, Stephens RL Jr, Binns BC, Chu Y, Sepkuty JP, Johns RA, Rothstein JD, Tao YX (2005) Spinal glutamate uptake is critical for maintaining normal sensory transmission in rat spinal cord. Pain 115(1-2):60-70

68. Weng HR, Chen JH, Cata JP (2006) Inhibition of glutamate uptake in the spinal cord induces hyperalgesia and increased responses of spinal dorsal horn neurons to peripheral afferent stimulation. Neuroscience 138(4):1351-1360

69. Nie H, Weng HR (2009) Glutamate transporters prevent excessive activation of NMDA receptors and extrasynaptic glutamate spillover in the spinal dorsal horn. J Neurophysiol 101(4):2041-2051

70. Narita M, Miyoshi K, Narita M, Suzuki T (2007) Changes in function of NMDA receptor NR2B subunit in spinal cord of rats with neuropathy following chronic ethanol consumption. Life Sci 80(9):852-859

71. Wang EM, Li WT, Yan XJ, Chen X, Liu Q, Feng CC, Cao ZJ, Fang JY, Chen SL (2015) Vagal afferent-dependent cholecystokinin modulation of visceral pain requires central amygdala NMDANR2B receptors in rats. Neurogastroenterol Motil 27(9):1333-1343

72. Chacur M, Matos RJ, Alves AS, Rodrigues AC, Gutierrez V, Cury Y, Britto LR (2010) Participation of neuronal nitric oxide synthase in experimental neuropathic pain induced by sciatic nerve transection. Braz J Med Biol 43(4):367-376

73. Mukherjee P, Cinelli MA, Kang S, Silverman RB (2014) Development of nitric oxide synthase inhibitors for neurodegeneration and neuropathic pain. Chem Soc Rev 43(19):6814-6838

74. Ma ZL, Zhang W, Gu XP, Yang WS, Zeng YM (2007) Effects of intrathecal injection of prednisolone acetate on expression of NR2B subunit and nNOS in spinal cord of rats after chronic compression of dorsal root ganglia. Ann Clin Lab Sci 37(4):349-355

75. Zhang J, Zhang W, Sun Y, Liu Y, Song L, Ma Z, Gu X (2014) Activation of GRs-Akt-nNOs-NR2B signaling pathway by second dose GR agonist contributes to exacerbated hyperalgesia in a rat model of radicular pain. Mol Biol Rep 41(6):4053-4061

76. Mabuchi T, Shintani N, Matsumura S, Okuda-Ashitaka E, Hashimoto H, Muratani T, Minami T, Baba A et al (2004) Pituitary adenylate cyclase-activating polypeptide is required for the development of spinal sensitization and induction of neuropathic pain. J Neurosci 24(33):7283-7291

Publisher's Note Springer Nature remains neutral with regard to jurisdictional claims in published maps and institutional affiliations. 